\title{
Dating violence victimization, perceived gravity in dating violence behaviors, sexism, romantic love myths and emotional dependence between female and male adolescents
}

\author{
Verónica Marcos*1, Yurena Gancedo², Bárbara Castro ${ }^{1}$ y Adriana Selaya ${ }^{1,3}$ \\ ' Unidad de Psicología Forense Facultad de Psicología Universidad de Santiago de Compostela (Spain) \\ 2 Psicología Organizacional, Jurídica Forense y Metodología de las Ciencias del Comportamiento Facultad de \\ Psicología Universidad de Santiago de Compostela (Spain) \\ ${ }^{3}$ Department AIPSE, Universidad de Vigo (Spain)
}

- Recibido: 22 - 06 - 2020 - Aceptado: 26 - 06 - 2020 . Avance online: 10 - 07 - 2020

ABSTRACT. A field study was designed to determine whether gender differences exist among adolescents in self-reported victimization of dating violence, perceived gravity of dating violence behaviors, sexism, myths about romantic love and emotional dependence. For that purpose, a random sample of 246 adolescents, 125 girls and 123 boys, aged from 14 to 17 years $(M=15.39$; SD =0.95), was selected from the community and answered with instruments to measure the victimization of dating violence, perceived gravity of dating violence behaviors, sexism, myths about romantic love and emotional dependence. The results showed that girls perceived more gravity in dating violence behaviors than boys; that boys and girls equally reported being victims of dating violence, except for physical violence victimization which was more reported by boys; and that boys revealed greater emotional dependence, romantic love myths and sexism than girls. In addition, we observed that these variables were significantly correlated with each other. Finally, the implications of the results for the design of prevention and intervention programs with adolescents are discussed.

KEYWORDS: Victimization, Relationships, Sexism, Romantic love myths, Emotional dependence, Adolescents.

Victimización de violencia entre novios, gravedad percibida en las conductas de violencia entre novios, mitos del amor romántico, y dependencia emocional entre chicos y chicas adolescentes

RESUMEN. Con el objetivo de conocer si existen diferencias de género entre los adolescentes en victimización autoinformada de violencia entre novios, percepción de la gravedad de las conductas de violencia entre novios, sexismo, sexismo, mitos del amor romántico y dependencia emocional, se diseñó un estudio de campo. Para ello, se tomó aleatoriamente de la comunidad a 246 adolescentes, 125 chicas y 123 chicos, aged from 14 to 17 years $(M=15.39$; SD =0.95), que respondieron a instrumentos de medida de la victimización de violencia entre novios, gravedad percibida de las conductas de violencia entre novios, sexismo, mitos sobre el amor romántico y dependencia emocional. Los resultados mostraron que las chicas percibían más gravedad en las conductas de violencia que los chicos; que chicos y chicas informaban por un igual ser víctimas de violencia entre novios, a excepción de victimización de violencia física que fue más informada por los chicos; y que los chicos manifestaron una mayor dependencia emocional, una mayor creencia en el amor romántico y sexismo que las chicas. Adicionalmente observamos que estas variables estaban significativamente correlacionadas entre sí. Finalmente, se discuten las implicaciones de los resultados para los diseños de programas de prevención e intervención con adolescentes.

PALABRAS CLAVE: Victimización, Relaciones de pareja, Sexism, Mitos del amor romántico, Dependencia emocional, Adolescentes.

*Correspondencia: Verónica Marcos.

Unidad de Psicología Forense Facultad de Psicología Universidad de Santiago de Compostela (España).

C.P: 15782, Santiago de Compostela, España.

E-mail: veronica.marcos.martinez@usc.es

(C) 2020 Sociedad Universitaria de Investigación en Psicologíay Salud. Publicado por Consejo General de Colegios Oficiales de Psicólogos, España. Este es un artículo Open Access
bajo la CC BY-NC-ND licencia (http://creativecommons.org/licencias/by-nc-nd/4.0/)

Citar como/Cite as: Marcos, V., Gancedo, Y., Castro, B. y Selaya, A. (2020). Dating violence victimization, perceived gravity in dating violence behaviors, sexism, romantic love myths and emotional dependence between female and male adolescents . Revista lberoamericana de Psicología y Salud, $17(2), 132-145$. Doi: https://doi.org/10.23923/i.rips.2020.02.040
Adolescence is a critical stage for the development of an individual, in which important physical, psychoemotional and social changes occur (Azdemir, Utkualp, \& Pallo, 2016; Viejo \& Ortega-Ruiz, 2015). In this period, teenagers begin to meet potential couples and 
experience romantic relationships (Connolly \& Mclsaac, 2009; Tuval-Mashiach, Walsh, Harel, \& Shulman, 2008). However, these relationships are not always positive, sometimes violent dynamics and abusive behaviour can develop within them. Dating Violence has been defined as "as physical, sexual, psychological or emotional aggression in a courtship relationship to control, dominate, or feel superior in the relationship" made up of adolescents or youth (Centers for Disease Control and Prevention [CDCP], 2007). The Spanish National Institute of Statistics (INE) alerted about the high number of complaints regarding this type of violence by minors, reaching 653 in 2017 and 677 in 2018 (INE, 2018). Internationally, the levels of violence received in courtship range from $0.4 \%$ to $57.3 \%$ for physics, between $8.5 \%$ and $95.5 \%$ for psychological and between $0.1 \%$ and $64.6 \%$ for sexual. In terms of violence, these figures range from $3.8 \%$ to $41.9 \%$ for physics, from $4.2 \%$ to $97 \%$ for psychological and from $1.2 \%$ to $58.8 \%$ for sexual (Rubio-Garay et al., 2017). This discrepancy in prevalence rates is due to the taking of different definitions of violence in adolescent courtship, and by extension, to the use of also different measures (Gallego, Novo, Fariña, \& Arce, 2019), although it is currently considered a highly prevalent phenomenon (Rubio-Garay, López-González, Carrasco, \& Amor, 2017; Yanez-Peñúñuri, Martínez-Gómez \& Rey-Anacona, 2019; Wincentak, Connolly, \& Card, 2017).

Unlike violence between adult couples, violence in teenage courtship is characterized by the dual role of aggressor and victim that many adolescents play in their love relationships (Marcos, Gancedo, Selaya, \& Novo, 2019; Moral, García, Cuetos, \& Sirvent, 2017; Carrascosa, Cava \& Buelga, 2018; Elder, Monks, Sánchez, \& Ortega-Ruiz, 2016). Therefore, the researchers warn of reciprocity in the execution of violent acts by both members of the couple (Alegria \& Rodriguez, 2015; Moral et al., 2017; Rubio-Garay, Carrasco, Amor, \& López-González, 2015). Although in DV the different types of physical, psychological and sexual violence occur simultaneously (Alegria \& Rodriguez, 2015; Rubio-Garay et al., 2017), the prevalence of different forms is not the same for both genders. Like this, boys tend to exercise more sexual violence (Rubio-Garay et al., 2017), while girls more perpetuate psychological violence (Alegría \& Rodríguez, 2015). As for physical violence, there are no conclusive results, as some studies indicate that in more done by boys (Rubio-Garay et al., 2017), while others point out otherwise (Rey-Anacona, 2013).

In addition, adolescents who are involved in intimate partner violence experience consequences at the physical, relational and behavioral level (Cava, Buelga, \& Tomás, 2018; Foshee et al., 2016; Vagi, O'Malley, Basile, \& Vivolo-Kantor, 2015), such as anxiety, under self-concept and depression, among others (Carrascosa, Cava \& Buelga, 2016; Carrascosa et al., 2018). Studies warn that this type of damage can be transferred to adulthood (ExnerCortens, Eckenrode \& Rothman, 2013; Sunday et al., 2011), being a risk factor for future aggressions in the adult couple (Rubio-Garay, Ortiz \& García-Rodríguez, 2019). On the other hand, those young people who are able to maintain positive intimate relationships present greater adaptation and satisfaction in their adult stage (Adamczyk \& Segrin 2016).

Based on the above, it can be said that the processes of victimization between adolescents and young people in their relationships represent a serious social and public health problem (Kings, Foshee, Niolon, Reidy, \& Hall, 2016; Rothman \& Xuan, 2013; Soller, Copp, Haynie, \& Kuhlemeier, 2020), whose analysis must be approached from a gender perspective through an analysis of cognitions that can act as underlying explanatory mechanisms of violent behavior (Nava-Reyes, Rojas-Solís, Greathouse, \& Morales, 2018; Novo, Fariña, Seijo, \& Arce, 2012).

\section{-PERCEIVED GRAVITY OF DATING VIOLENCE BEHAVIORS}

According to the Gender Schema Theory (Bem, 1981), within the framework of the SocioCultural Feminist Theory, the dichotomization of the masculine and the feminine gives rise to the creation of gender schemes, cognitive constructs that are internalized from early childhood, with differential and unique characteristics for men and women, which are decisive for the 
development of individuals. In this way, they will process the information in different ways, leading them to different experiences of the same events (Bem, 1981, 1983). Gender schemes can therefore affect perceptions of violence, the most consistent with the male and socially most accepted role of men (Bem, 1981). Likewise, the role of the female gender is linked with qualities such as submission and passivity, versus the masculine, which relates to strength, aggression and dominance (Hyde, 2005; McHugh \& Frieze, 1997; Reyes et al., 2016). From this positioning, men value violence as less problematic than women, which leads to them having less sense of gravity about those behaviors that constitute violence in relationships (Hamby \& Jackson, 2010) and, consequently, that they accept to a greater extent violence against girls (Dardis, Edwards, Kelley, \& Gidycz, 2013, 2015; Hamby \& Jackson, 2010). The perceived gravity of dating violence behaviors could be a key element in preventing victimization and yet this relationship has been poorly investigated (Ameral, Reed, \& Hines, 2017; Sánchez, Sobral, \& Seijo, 2016).

\section{-SEXIST BELIEFS AND ROMANTIC LOVE MYTHS}

Gender schemes, in their relationship to cognitive aspects, affect each person's beliefs and, consequently, to the links between women and mens (Nava-Reyes et al., 2018; Novo, Herbon, \& Amado, 2016). Specifically, sexist attitudes form part of the basis of courtship relationships among oung people. According to Glick and Fiske's Theory of Ambivalent Sexism (1996, $1999,2001)$, there is a differentiation of power in relations between women and men, where sexist attitudes have considerable ambivalence on the part of each sex towards the other. Under this theory, sexism is a multidimensional construct, the result of the combination of hostile sexism, characterized by assuming a stereotypical and negative view of women as inferior; and benevolent sexism, based on considering weak women, in need of the protection of men (Glick \& Fiske, 1996, 1999, 2001). According to this, teenagers who exhibit sexist attitudes maintain behaviors prone to intimate partner violence (Rey-Anacona, Cruz, Jimenez, \& Guajardo 2017; Fernández-Fuertes, Carcedo, Orgaz, \&
Fuertes, 2018), presenting higher sexism scores the boys (Pradas \& Perles, 2012). In addition, research based on this positioning suggests that people who support sexist attitudes have a greater acceptance of myths than those who do not (Camplá, Novo, Sanmarco, \& Arce, 2019).

Among the strongly ingrained and socially accepted beliefs that can be held about love (Yela, 2003) are the myths of romantic love, such as "love can do everything" or "jealousy are a test of love'. These beliefs minimize the perception of aggression within the couple, as many teenagers justify violence through them (Ferrer, Bosch, \& Navarro, 2010; MartínezLeón, Mathes, Avendaño, Peña, \& Sierra, 2018; Rodríguez-Castro, Lameiras-Fernández, CarreraFernández, \& Vallejo-Medina, 2013). In this way, sexist myths and attitudes can be flattering elements of the continuity and permanence of violence in courtship (Rubio-Garay et al., 2015). However, the results are also contradictory in terms of gender differences, some studies indicate that they have higher prevalence of myths (Bisquert-Bover, Giménez-García, GilJuliá, Martínez-Gómez, \& Gil-Llario, 2019), other research reflects that it is the girls who have the greatest adherence to myths (Bosch et al., 2010; Moroccan \& Cervera, 2014).

\section{- EMOTIONAL DEPENDENCE}

Management of management and emotional expression is essential in promoting positive and healthy relationships (Morrish, Rickard, Chin \& Vella-Brodrick, 2018). However, adolescence is a period characterized mainly by difficulty controlling emotions, especially in loving relationships. The concept of emotional dependence has been widely examined in the field of violence on adolescent partners (Cañete \& Díaz, 2019; Moral et al., 2017; Urbiola \& Estevez, 2015). This term refers to an extreme need for affection from one person to another (Pradas \& Perles, 2012). Within the context of the couple, dependents do not imagine their existence without their partner, which causes a great deal of inappropriate behaviors as long as the relationship does not end (Izquierdo \& Gómez-Acosta, 2013; Skvortsova \& Shumskiy, 2014). In this sense, adolescents who reflect 
greater emotional dependence present an increased risk of intimate partner violence (Moral et al., 2017). As for gender differences, they are also not conclusive, some research reveals that kids have higher scores in emotional dependence (Moral et al., 2017; Urbiola \& Estevez, 2015), compared to others that reflect higher scores the girls (Alonso-Arbiol, Shaver, \& Yárnoz, 2002; Ehrenberg \& Saffrey, 2007).

\section{- RESEARCH AIMS AND HYPOTHESES}

Taking into account the literature set out above our research aims to analyze a lesserknown aspect of dating violence, the perception of the gravity that adolescents present about such dating violence behaviors, from a gender perspective (European Commision, 2009). Thus, in this work we are interested in analyzing gender differences in perceived gravity and victimization, as well as in associated variables such as sexist beliefs and myths or emotional dependence. In addition, taking into account the variables included in this study, we aim to lay the foundations for an explanatory model of the perception of gravity that takes into account gender differences.

\section{METHOD}

\section{-PARTICIPANTS}

The study involved 246 subjects, 125 women (50.8\%) and 123 men (49.2\%), aged between 14 and 17 years $(M=15.39$; $S D=$ 0.949). In terms of the course, $29.3 \%$ belonged to third of ESO, 32.1\% were in fourth of ESO and $38.6 \%$ were first of Bachiller. Regarding the repetition of the course, $89.4 \%$ indicated never repeating, compared to $8.5 \%$ and $2.0 \%$ that they scored once and twice, respectively.

\section{-PROCEDURE AND DESIGN}

To obtain the sample, authorization with the school was processed, the consent of the parents and the willfulness of the participants. Then, a random sample of adolescents was taken from the school. All participants completed the instruments, responding individually and anonymously. The instruments were managed by staff trained in person and in a single session with each group ( 9 groups in total).

\section{-MEASUREMENT INSTRUMENTS}

A questionnaire to measure sociodemographic variables was used: gender, age, course, course repetition and province.

The Dating Violence Questionnarie- $R$ (DVQ-R) (CUVINO-R; Rodríguez-Díaz, Herrero, Rodríguez-Franco, Bringas-Molleda, PaínoQuesada y Pérez, 2017) was used to evaluate the experience of victimization in young people within a couple's relationship. Subjects responded to this instrument on a 5 -points Likert scale $(0=$ never, $1=$ one time, $2=$ sometimes, $3=$ many times, $4=$ all the time). This instrument consists of five factors: Physical ( $\alpha=.75)$, Sexual $(\alpha=$ .74), Humiliation $(\alpha=.72)$, Detachment $(\alpha=$ $.68)$, and Coercion ( $\alpha=.64)$. The total scale was internally consistent ( $\alpha=.85)$. Specifically, in this study, the reliability for the total scale was of $\alpha=.92$, with values of $\alpha=.86$ for the Physical subscale, of $\alpha=.80$ for the Sexual subescale, of $\alpha=.84$ for the Humiliation subescale, of $\alpha=.68$ for the Detachment subescale, and of $\alpha=.71$ for the Coercion subescale. In addition, the scale was modified incorporating the perceived gravity of dating violence behaviors, on a 5-points Likert scale $(1=$ nothing serious, 2 = almost nothing serious, 3 = little serious, $4=$ pretty serious, 5 $=$ very serious). Internal consitency was of of $\alpha$ $=.96$.

As for measuring, the Escala de Sexismo [Scale of Sexism] of Recio, Square \& Ramos (2007), consisting of 26 items, was used. This instrument is divided into two factors: benevolent sexism and hostile sexism. The subjects responded to this measure on a 6 -points Likert- scale $10=$ totally disagree, 1 = moderately disagree, $2=$ disagree, 3 =agree, $4=$ moderately agree, and 5 = strongly agree). In our sastudy the internal consistency was of $\alpha=.92$ for the total scale and of $\alpha=.91$ for the Hostile Sexism subscale and of $\alpha=085$ for Benevolent Sexism subescale.

The Myths Scale towards Love (RodríguezCastro et al., 2013) was used. It consists of 7 items, divided into two factors: myth of the idealization of romantic love and the myth of the 
love-abuse bond. The scale presented adequate reliabilitys ( $\alpha=.70$ and $\alpha=0.86$, respectively). The subjects responded to this instrument on a 5-points Likert scale ( 1 = totally disagree, $2=$ disagree, $3=$ neither agree nor disagree, $4=$ agree and $5=$ totally agree). The total scale was shown to be internally consistent $(\alpha=0.71)$.

The Emotional Dependency Scale in youth and adolescent courtship to measure the expression of emotional dependence on relationships (DEN; Urbiola, Estevez \& Iraurgi, 2014) was administered. This instrument consists of 12 items grouped into four dimensions: avoid being alone, need/exclusivity, need to please and asymmetric ratio. Subjects responded to this measurement on a 6-points Likert scale $0=$ never, $1=$ one time, $2=$ sometimes, $3=$ many times, 4 = almost always, and 5 =always). In this study, the total scale obtained a coefficient of reliability of $\alpha=.89$.

\section{- DATA ANALYSIS}

A Student t-test for independent samples to examine gender differences in the variables under study was used. The size of the effect was also analyzed using Cohen's d, the parameters of which are set between 0.20 (small), 0.50 (medium) and 0.80 (large) (Cohen, 1992). Correlations through Pearson's $r$ to analyze the relationship between variables were calculated.

\section{RESULTS}

First, the difference in means in perceived gravity of dating violence behaviors was found (see Table 1). The results reflected significant differences in gender, featuring higher scores for girls, with low and medium effect sizes, with the exception of the detachment factor, where no significant differences between boys and girls were found.

Tabla 1

Gender differences in Perceived Gravity of Dating Violence Behaviors

\begin{tabular}{|c|c|c|c|c|c|c|c|}
\hline Variable & Gender & $N$ & $t(d f)$ & $p$ & $M(S D)$ & $95 \% \mathrm{Cl}$ & $d$ \\
\hline PHYSICAL & $\begin{array}{l}\text { Girls } \\
\text { Boys }\end{array}$ & $\begin{array}{c}101 \\
79\end{array}$ & $2.84(150)$ & .005 & $\begin{array}{l}14.84(2.87) \\
13.46(3.44)\end{array}$ & $\begin{array}{l}0.42 \\
2.32\end{array}$ & 0.44 \\
\hline SEXUAL & $\begin{array}{l}\text { Girls } \\
\text { Boys }\end{array}$ & $\begin{array}{c}109 \\
81\end{array}$ & $3.82(148)$ & .000 & $\begin{array}{l}14.98(2.75) \\
13.19(3.46)\end{array}$ & $\begin{array}{l}0.86 \\
2.70\end{array}$ & 0.58 \\
\hline HUMILIATION & $\begin{array}{l}\text { Girls } \\
\text { Boys }\end{array}$ & $\begin{array}{c}105 \\
82\end{array}$ & $2.41(185)$ & .017 & $\begin{array}{l}14.51(2.88) \\
13.45(3.10)\end{array}$ & $\begin{array}{l}0.19 \\
1.93\end{array}$ & 0.35 \\
\hline DETACHMENT & $\begin{array}{l}\text { Girls } \\
\text { Boys }\end{array}$ & $\begin{array}{c}110 \\
80\end{array}$ & $1.67188)$ & .096 & $\begin{array}{l}12.60(3.03) \\
11.81(3.41)\end{array}$ & $\begin{array}{c}-0.14 \\
1.71\end{array}$ & 0.25 \\
\hline COERCION & $\begin{array}{l}\text { Girls } \\
\text { Boys }\end{array}$ & $\begin{array}{c}105 \\
84\end{array}$ & $2.85(164)$ & .005 & $\begin{array}{l}13.12(3.08) \\
11.71(3.59)\end{array}$ & $\begin{array}{l}0.43 \\
2.38\end{array}$ & 0.42 \\
\hline
\end{tabular}

Tabla 2

Gender differences in Dating Violence Victimization

\begin{tabular}{|c|c|c|c|c|c|c|c|}
\hline Variable & Gender & $N$ & $t(d f)$ & $p$ & $M(S D)$ & $95 \% \mathrm{Cl}$ & $d$ \\
\hline PHYSICAL & $\begin{array}{l}\text { Girls } \\
\text { Boys }\end{array}$ & $\begin{array}{l}121 \\
113\end{array}$ & $-2.04(133)$ & .042 & $\begin{array}{l}0.11(0.51) \\
0.44(1.61)\end{array}$ & $-0.63,-0.02$ & -0.30 \\
\hline SEXUAL & $\begin{array}{l}\text { Girls } \\
\text { Boys }\end{array}$ & $\begin{array}{l}123 \\
115\end{array}$ & $-0.91(236)$ & .928 & $\begin{array}{l}0.34(1.10) \\
0.36(1.53)\end{array}$ & $-0.35,0.32$ & -0.02 \\
\hline HUMILIATION & $\begin{array}{l}\text { Girls } \\
\text { Boys }\end{array}$ & $\begin{array}{l}122 \\
115\end{array}$ & $-1.53(157)$ & .126 & $\begin{array}{l}0.23(0.80) \\
0.51(1.75)\end{array}$ & $-0.62,0.07$ & -0.21 \\
\hline DETACHMENT & $\begin{array}{l}\text { Girls } \\
\text { Boys }\end{array}$ & $\begin{array}{l}124 \\
114\end{array}$ & $0.54(236)$ & .587 & $\begin{array}{l}1.25(2.22) \\
1.10(1.87)\end{array}$ & $-0.38,0.67$ & 0.07 \\
\hline COERCION & $\begin{array}{l}\text { Girls } \\
\text { Boys }\end{array}$ & $\begin{array}{l}123 \\
114\end{array}$ & $-0.27(235)$ & .782 & $\begin{array}{l}0.60(1.48) \\
0.66(1.67)\end{array}$ & $-0.46,0.34$ & -0.04 \\
\hline
\end{tabular}


In terms of the dating violence victimization, no significant differences in the factors were found, except for the physical factor, in which the boys scored higher (see Table 2).

In table 3, following the same procedure, examined the difference in means in beliefs (hostile sexism, benevolent sexism, and romantic love myths). Significant differences between girls and boys in hostile sexism, benevolent sexism and romantic love myths, with higher scores on the part of boys were confirmed.

In examining the difference in means in expression of emotional dependence in couple of relationships, the results reflected significant differences in dimensions avoiding being alone, need for exclusivity and need to please between girls and boys. However, no significant differences between the two groups in the asymmetrical relationship (see Table 4) were found.

As for the correlations between perceived gravity, victimization, sexist beliefs (hostile sexism and benevolent sexism), myths about romantic love and emotional dependence (see Table 5), significant relationships were found between perceived gravity and victimization, this relationship being inverse and significant. In addition, significant inverse relationships between perceived gravity with hostile sexism, benevolent sexism and myths were found. As for victimization, significant relationships with hostile sexism, benevolent sexism, myths and the four subscales of emotional dependence were found.

Tabla 3

Gender differences in Sexist Beliefs and Myths of Romantic Love

\begin{tabular}{|c|c|c|c|c|c|c|c|}
\hline Variable & Gender & $N$ & $t(d f)$ & $p$ & $M(S D)$ & $95 \% \mathrm{Cl}$ & $d$ \\
\hline HOSTILE SEXISM & $\begin{array}{c}\text { Girls } \\
\text { Boys }\end{array}$ & $\begin{array}{l}120 \\
113\end{array}$ & $-4.30(135)$ & .000 & $\begin{array}{l}15.40(3.02) \\
19.28(9.11)\end{array}$ & $-5.6,-2.09$ & -0.58 \\
\hline BENEVOLENT SEXISM & $\begin{array}{c}\text { Girls } \\
\text { Boys }\end{array}$ & 122 & $-3.07(225)$ & .002 & $\begin{array}{l}15.50(6.68) \\
18.45(8.05)\end{array}$ & $-4.84,-1.06$ & -0.39 \\
\hline $\begin{array}{c}\text { MYTH ABOUT } \\
\text { IDEALIZATION LOVE }\end{array}$ & $\begin{array}{c}\text { Girls } \\
\text { Boys }\end{array}$ & 117 & $-2.10(238)$ & .037 & $\begin{array}{l}12.67(4.03) \\
13.80(4.32)\end{array}$ & $-2.19,-0.07$ & -0.27 \\
\hline $\begin{array}{c}\text { MYTH OF THE LOVE- } \\
\text { ABUSE BOND }\end{array}$ & $\begin{array}{c}\text { Girls } \\
\text { Boys }\end{array}$ & 1125 & $-2.88(177)$ & .004 & $\begin{array}{l}2.21(0.80) \\
2.65(1.50)\end{array}$ & $-0.75,-0.14$ & -0.37 \\
\hline
\end{tabular}

Tabla 4

Gender differences in Emotional Dependence

\begin{tabular}{|c|c|c|c|c|c|c|c|}
\hline Variable & Gender & $N$ & $t(d f)$ & $p$ & $M(S D)$ & $95 \% \mathrm{Cl}$ & $d$ \\
\hline AVOID BEING ALONG & $\begin{array}{c}\text { Girls } \\
\text { Boys }\end{array}$ & $\begin{array}{l}122 \\
116\end{array}$ & $-3.66(170)$ & .000 & $\begin{array}{l}1.17(1.38) \\
2.19(2.69)\end{array}$ & $-1.57,-0.47$ & -0.48 \\
\hline NEED/EXCLUSIVITY & $\begin{array}{c}\text { Girls } \\
\text { Boys }\end{array}$ & 119 & $-4.69(176)$ & .000 & $\begin{array}{l}1.00(1.66) \\
2.46(2.90)\end{array}$ & $-2.08,-0.85$ & -0.62 \\
\hline NEED TO PLEASE & $\begin{array}{l}\text { Girls } \\
\text { Boys }\end{array}$ & 117 & $-5.78(182)$ & .000 & $\begin{array}{l}1.18(1.97) \\
3.28(3.40)\end{array}$ & $-2.81,-1.38$ & -0.76 \\
\hline ASYMMETRIC RATIO & $\begin{array}{l}\text { Girls } \\
\text { Boys }\end{array}$ & 116 & $-1.89(216)$ & .059 & $\begin{array}{l}1.60(2.27) \\
2.26(2.99)\end{array}$ & $-1.33,0.025$ & -0.25 \\
\hline
\end{tabular}


Tabla 5

Pearson's Correlations among Variables

\begin{tabular}{|c|c|c|c|c|c|c|c|c|c|c|c|c|c|c|c|c|c|}
\hline & 1 & 2 & 3 & 4 & 5 & 6 & 7 & 8 & 9 & 10 & 11 & 12 & 13 & 14 & 15 & 16 & 17 \\
\hline PHYSICAL (M) & - & & & & & & & & & & & & & & & & \\
\hline SEXUAL (M) & $.766^{* *}$ & - & & & & & & & & & & & & & & & \\
\hline $\begin{array}{l}\text { HUMILIATION } \\
(\mathrm{N})\end{array}$ & $.803^{* *}$ & $.711^{* *}$ & - & & & & & & & & & & & & & & \\
\hline $\begin{array}{l}\text { DETACHMENT } \\
(\mathrm{V})\end{array}$ & $.521^{* *}$ & $.551^{\star *}$ & $.609^{* *}$ & - & & & & & & & & & & & & & \\
\hline $\begin{array}{c}\text { COERCION } \\
(\mathrm{N})\end{array}$ & $.700^{* *}$ & $.678^{* *}$ & $.750^{* *}$ & $.679^{* *}$ & - & & & & & & & & & & & & \\
\hline PHYSICAL (P) & $-.187^{*}$ & -.083 & -.084 & .022 & -.071 & - & & & & & & & & & & & \\
\hline SEXUAL (P) & $-.330^{* *}$ & $-.168^{*}$ & $-.160^{*}$ & -.059 & -.119 & $.861^{* *}$ & - & & & & & & & & & & \\
\hline $\begin{array}{l}\text { HUMILIATION } \\
\text { (P) }\end{array}$ & $-.284^{* *}$ & -.087 & $-.166^{*}$ & -.110 & $-.189^{*}$ & $.842^{* * *}$ & $.873^{* *}$ & - & & & & & & & & & \\
\hline $\begin{array}{l}\text { DETACHMENT } \\
\text { (P) }\end{array}$ & $-.237^{* *}$ & -.053 & -.124 & $-.161^{*}$ & -140 & $.682^{* *}$ & $.748^{* *}$ & $.805^{* *}$ & - & & & & & & & & \\
\hline $\begin{array}{c}\text { COERCION } \\
(\mathrm{P})\end{array}$ & - $-190^{*}$ & -.077 & -.086 & -.121 & $-.241^{* *}$ & $.742^{* *}$ & $.800^{* *}$ & $.848^{* *}$ & $.810^{* *}$ & - & & & & & & & \\
\hline $\begin{array}{l}\text { HOSTILE } \\
\text { SEXISM }\end{array}$ & $.319^{* *}$ & $.333^{* *}$ & $.263^{* *}$ & .081 & $.198^{* *}$ & $-.270^{* *}$ & $-.258^{* *}$ & -.131 & $-.172^{*}$ & $-.281^{* *}$ & - & & & & & & \\
\hline $\begin{array}{l}\text { BENEVOLENT } \\
\text { SEXISM }\end{array}$ & $.186^{* *}$ & $.209^{* *}$ & $.159^{*}$ & .128 & $.166^{*}$ & $-.291^{* *}$ & $-.314^{* *}$ & $-.299^{* *}$ & $-.261^{* *}$ & $-.387^{* *}$ & $.675^{\star *}$ & - & & & & & \\
\hline $\begin{array}{c}\text { MYTH } \\
\text { ABOUT THE } \\
\text { IDEALIZATION } \\
\text { OF LOVE }\end{array}$ & $.172^{* *}$ & .125 & $.132^{*}$ & .091 & $.172^{* *}$ & -.140 & $-.211^{* *}$ & -.111 & -.072 & -.114 & $.229^{* *}$ & $.248^{* *}$ & - & & & & \\
\hline $\begin{array}{l}\text { MYTH OF THE } \\
\text { LOVE-ABUSE } \\
\text { BOND }\end{array}$ & $.259^{* *}$ & $.371^{* *}$ & $251^{* *}$ & $.178^{* *}$ & $.342^{* *}$ & $-.193^{* *}$ & $-.206^{* *}$ & $-.170^{*}$ & $-.160^{*}$ & $-281^{* *}$ & $.366^{* *}$ & $.302^{* *}$ & $272^{* *}$ & - & & & \\
\hline $\begin{array}{c}\text { AVOID BEING } \\
\text { ALONG }\end{array}$ & $.285^{* *}$ & $.251^{* *}$ & $.326^{* *}$ & $.236^{* *}$ & .293 & -.004 & -.104 & -.077 & -.030 & -.092 & $.157^{*}$ & $.253^{* *}$ & $.322^{* *}$ & $.177^{* *}$ & - & & \\
\hline $\begin{array}{c}\text { NEED/ } \\
\text { EXCLUSIVITY }\end{array}$ & $.263^{* *}$ & $.252^{* *}$ & $.284^{* *}$ & $.217^{* *}$ & .310 & -.079 & $-.194^{* *}$ & $-.180^{*}$ & -.072 & $-.203^{* *}$ & $.144^{*}$ & $.329^{* *}$ & $391^{* *}$ & $.274^{* *}$ & $.687^{\star *}$ & - & \\
\hline $\begin{array}{l}\text { NEED TO } \\
\text { PLEASE }\end{array}$ & $259^{* *}$ & $.138^{*}$ & $.268^{* *}$ & $.190^{* *}$ & .231 & -.069 & $-.207^{* *}$ & $-.179^{*}$ & - -116 & $-.193^{* *}$ & $.165^{*}$ & $.283^{* *}$ & $.307^{* *}$ & $.147^{*}$ & $.671^{* *}$ & $.755^{* *}$ & - \\
\hline $\begin{array}{c}\text { ASYMMETRIC } \\
\text { RATIO }\end{array}$ & $.251^{* *}$ & $.294^{* *}$ & $.395^{* *}$ & $.305^{* *}$ & .381 & -.062 & -.124 & -.095 & -.062 & -.145 & $.163^{*}$ & $.330^{* *}$ & $.361^{\star *}$ & $.249^{* *}$ & $.646^{* *}$ & $.668^{* *}$ & $.572^{* \star}$ \\
\hline
\end{tabular}




\section{DISCUSSION}

Our research presents a number of limitations to consider when generalizing and extrapolating the results. First, the participants' responses may be mediated by social desirability or denial, two forms of disguise (Arce, Fariña, Seijo, \& Novo, 2015; Fariña, Redondo, Seijo, Novo, \& Arce, 2017). Second, the size and heterogeneity of the sample, since the participants belong to a specific geographical scope. Third, this study should be supplemented by other variables that interact with gender beliefs, such as socio-community factors (Fariña, Arce, \& Novo, 2008), family or personal (Corrás, Seijo, Fariña, Novo, Arce, \& Cabanach, 2017).

In relation to the perceived gravity on dating violence, our results reveal significant gender differences, given that girls perceive dating violence behaviors as more serious than boys, with the exception of detached behaviors in which there are no differences, and consequently less acceptance of violent dating behaviors (Dardis et al., 2013; Dardis et al., 2015; Hamby and Jackson, 2010). We also found gender differences in sexist beliefs and myths of romantic love, with boys scoring higher on these variables, according to other research (Bisquert-Bover et al, 2019; Pradas and Perles, 2012), reproducing traditional gender schemes where the female role is linked to submission and passivity; versus the male role which is related to strength, aggressiveness and dominance (Hyde 2005; McHugh and Frieze, 1997; Reyes et al., 2016), and which can affect perceptions of violence (Ameral et al., 2017; Dardis et al., 2015; Novo et al, 2016).

On the other hand, our results reflect that there are no gender differences in victimization. This corroborates the existence of reciprocity of violence by both members of the partner, the main feature of the DV, as indicated by the literature (Alegria \& Rodriguez, 2015; Moral et al., 2017; Carrascosa et al., 2018; Viejo et al., 2016), with the exception of the physical one, where in our study there were significant differences in gender, presenting higher scores the boys. In addition, our results support the relationship between victimization in relationships with sexist beliefs and myths of romantic love (Rey-Anacona et al.,
2017; Fernández-Fuertes et al., 2018; Pradas \& Perles, 2012), showing that sexist attitudes and myths can be flattering elements of the beginning and continuity of dating violence (Rubio-Garay et al., 2015), and that they must therefore be included as a content of programs to prevent victimization in courtship. Therefore, for effective prevention, the reduction of sexist beliefs, gender stereotypes and myths about love (De La Rue, Polanin, Espelage, \& Pigott, 2014 ; Muñoz-Rivas, Redondo-Rodríguez, \& Ronzón-Tirado, 2019; Reyes et al., 2016), as it can be a protective factor against violence in the loving relationship (Garrido \& Casas, 2009; Montolío, Ros, \& Portela, 2016).

Regarding emotional dependence, our results also reflect significant differences in gender, with greater emotional dependence. That is, kids have a more need for exclusivity, being alone, and pleasing. In addition, the subscales of emotional dependence were significantly and directly related to sexist beliefs, myths and victimization behaviors. In this sense, it should be noted that deficits in emotional competition (Salovey, Mayer, Goldman, Turvey, \& Palfai, 1995), hinder empathy, control and emotional regulation and, by extension, facilitate emotional deregulation, which relates to antisocial and criminal behaviors (Arce, Seijo, Fariña \& Mohamed-Mohand, 2010; Ferriz, Sobral \& Gómez-Fraguela, 2018). In fact, it has been found that inadequate management of emotions to be inversely associated with physical, psychological and sexual violence (Stappenbeck, Davis, Cherf, Gulati, \& Kajumulo, 2016). Therefore, the development of adaptive forms to respond to emotions could also act as a protective factor against violence in adolescent courtship (Fernández-González, Calvete, Orue, \& Echezarraga, 2018) that can be considered in the design of preventive strategies.

In the face of intervention, the perceived gravity can be considered as a dynamic, modifiable and therefore objective risk factor of the intervention (Basanta, Fariña, \& Arce; 2018; Bonta \& Andrews, 2016), in which gender differences are to be considered. All this will allow us to meet the recommendations of international organizations that demand an effort to prevent violence in adolescent courtship (CDCP, 2020), and to build capacity for prevention in order to 
reduce the risk of victimization (World Health Organization, 2014), implementing evidencebased programs of prevention and intervention (Novo, Fariña, Seijo, Vázquez, \& Arce, 2019; Yanez-Peñúñuri et al., 2019; Wincentak et al., 2017). However, it is necessary to further increase knowledge of the specific factors related to dating violence (Rubio-Garay et al., 2015), as well as in the establishment of rigid measurement criteria clearly defined for the classification of types of violence.

\section{- Conflict of interest.}

The authors declare no conflict of interest.

\section{REFERENCIAS}

Adamczyk, K., \& Segrin, C. (2016). The mediating role of romantic desolation and dating anxiety in the association between interpersonal competence and life satisfaction among polish young adults. Journal of Adult Development, 23(1), 1-10.

Alegría, M., \& Rodríguez, A. (2015). Violencia en el noviazgo: Perpetración, victimización y violencia mutua. Una revisión [Dating violence: Perpetration, and mutual violence. $A$ review]. Actualidades en Psicología, 29(1 18), 57-72. http://dx.doi.org/10.15517/ ap.v29i1 18.16008

Alonso-Arbiol, I., Shaver, P., \& Yárnoz, S. (2002). Insecure attachment, gender roles and interpersonal dependency in the Basque Country. Personal Relationships, 9, 479-490. https://doi.org/10.1111/1475-6811.00030

Ameral, V., Palm Reed, K. M., \& Hines, D. A. (2017). An analysis of help-seeking patterns among college student victims of sexual assault, dating violence, and stalking. Journal of Interpersonal Violence, 1-25. https://doi. org/10.1177/0886260517721169

Arce, R., Fariña, F., Seijo, D., \& Novo, M. (2015). Assessing impression management with the MMPI-2 in child custody litigation. Assessment, 22, 769-777. https://dx.doi. org/10.1177/1073191114558111

Arce, R., Seijo, D., Fariña, F., \& MohamedMohand, L. (2010). Comportamiento antisocial en menores: Riesgo social y trayectoria natural de desarrollo [Antisocial behavior in adolescents: Social risk and natural developmental trajectory]. Revista Mexicana de Psicología, 27(2), 127-142. Retrieved from https://www.redalyc.org/ pdf/2430/243016324002.pdf

Basanta, J. L., Fariña, F., \& Arce, R. (2018). Risk-need-responsivity model: Contrasting criminogenic and noncriminogenic needs in high and low risk juvenile offenders. Children and Youth Services Review, 85, 137-142. https://doi.org/10.1016/i. childyouth.2017.12.024

Bem, S. L. (1981). Gender schema theory: A cognitive account of sex typing. Psychological Review, 88(4), 354-364. https://doi. org/10.1037/0033-295X.88.4.354

Bem, S. L. (1983). Gender schema theory and its implications for child development: Raising gender-aschematic children in a genderschematic society. Journal of Women in Culture and Society, 8(4), 598-616. https:// doi.org/10.1086/493998

Bisquert-Bover, M., Giménez-García, C., GilJuliá, B., Martínez-Gómez, N., \& Gil-Llario, M. D. (2019). Mitos del amor romántico y autoestima en adolescentes International Journal of Developmental and Educational Psychology, 5(1), 507-518.

Bonta, J., \& Andrews, D. A. (2016). The psychology of criminal conduct (6th ed.). New York, NY: Routledge.

Camplá, X., Novo, M., Sanmarco. J., y Arce, R. (2019). Escala Acceptance of Modern Myths about Sexual Aggression: Validación para la población chilena [The Acceptance of Modern Myths about Sexual Aggression Scale: Validation for Chilean population]. Revista Mexicana de Psicología, 36(2), 132146. Recuperado de http://comeppsi.com/ images/rmp/RMP\%20362\%20132-146.pdf

Cañete, M. \& Díaz, L.D. (2019). La dependencia emocional y su relación con el sexismo en adolescentes [Emotional dependence and its relationship with sexism in adolescents]. International Journal of Sociology of Education, $8(3), \quad 236-260$. https://doi.org/10.17583/ rise. 2019.4198 
Carrascosa, L., Cava, M. J., \& Buelga, S. (2018). Psychosocial profile of Spanish Adolescent aggressors and victims of dating violence. Universitas Psychologica, 17(3), 183-193. http://dx.doi.org/10.11144/javeriana. upsy 17-3.ppae

Cava, M. J., Buelga, S., \& Tomás, I. (2018). Peer victimization and dating violence victimization: The mediating role of loneliness, depressed mood, and life satisfaction. Journal of Interpersonal Violence, 1-26. https://doi. org/10.1177/0886260518760013

Centers for Disease Control and Prevention (2007). Dating Matters: Strategies to Promote. Retrieved from https://www.cdc.gov/ violenceprevention/pdf/tdv-factsheet.pdf

Centers for Disease Control and Prevention (2020). Preventing Teen Dating Violence. Retrieved from https://www.cdc.gov/ violenceprevention/pdf/ipv/TDVfactsheet 2020.pdf

Connolly, J., \& Mclsaac, C. (2009). Adolescents' explanations for romantic dissolutions: A developmental perspective. Journal of Adolescence, 32(5), 1209-1223. https://doi. org/10.1016/i.adolescence.2009.01.006

Corrás, T., Seijo, D., Fariña, F., Novo, M., Arce, R., \& Cabanach, R. G. (2017). What and how much do children lose in academic settings owing to parental separation? Frontiers in Psychology, 8, 1545. http://doi.org/10.3389/ fpsyg.2017.01545

Dardis, C. M., Edwards, K. M., Kelley, E. L., \& Gidycz, C. A. (2013). Dating violence perpetration: The predictive roles of maternally versus paternally perpetrated childhood abuse and subsequent dating violence attitudes and behaviors. Journal of Agression, Maltreatment, \& Trauma, 22, 6-25. https://doi.org/10.1080 $\angle 10926771.2013 .743948$

Dardis, C. M., Edwards, K. M., Kelley, E. L., \& Gidycz, C. A. (2015). Perceptions of dating violence and associated correlates: A study of college young adults. Journal of Interpersonal Violence, 32(21), 3245-3271. https://doi. org/10.1177/0886260515597439

De La Rue, L., Polanin, Espelage, \& Pigott, T. (2014). School-based interventions to reduce dating and sexual violence: A systematic review. Campbell Systematic Reviews, 7, 1-1 10. https://doi.org/10.4073/csr.2014.7

Ehrenberg, M., \& Saffrey, C. (2007). When thinking hurts: Attachment, rumination and postrelationship adjustment. Personal Relationships, 14, 351-368. http://dx.doi. org/10.1111/i.1475-6811.2007.00160.x

Exner-Cortens, D., Eckenrode, J., \& Rothman, E. (2013). Longitudinal associations between teen dating violence victimization and adverse health outcomes. Pediatrics, 131(1), 71-78. https://doi.org/10.1542/peds.2012-1029

European Commission. (2009). She figures: Statistics and indicators on gender equality in science. Luxembourg: Publication Office of the European Commission. Retrieved from https://ec.europa.eu/research/sciencesociety/document library/pdf 06/she figures 2009 en.pdf

Fariña, F., Arce, R., \& Novo, M. (2008). Neighborhood and community factors: Effects on deviant behavior and social competence. Spanish Journal of Psychology, 17(1), 78-84. https://doi.org/10.1017/ S1138741600004133

Fariña, F., Redondo, L., Seijo, D., Novo, M., \& Arce, R. (2017). A meta-analytic review of the MMPI validity scales and indexes to detect defensiveness in custody evaluations. International Journal of Clinical and Health Psychology, 17(2), 128-138. https://doi. org/10.1016/i.ijchp.2017.02.002

Fernández-Fuertes, A. A., Carcedo, R. J., Orgaz, B., \& Fuertes, A. (2018). Sexual coercion perpetration and victimization: Gender similarities and differences in adolescence. Journal of Interpersonal Violence, 33(16), 2467-2485.

Fernández-González, L., Calvete, E., Orue, I., \& Echezarraga, A. (2018). The role of emotional intelligence in the maintenance of adolescent dating violence perpetration. Personality and Individual Differences, 127, 68-73. https:// doi.org/10.1016/i.paid.2018.01.038

Ferrer, V. A., Bosch, E., \& Navarro, C. (2010). Los mitos románticos en España. Boletín de Psicología, 99, 7-31. 
Férriz, L., Sobral, J., \& Gómez-Fraguela, A. (2018). Empatía y delincuencia juvenil: Un meta-análisis sobre la relación [Empathy and juvenile delinquency: A meta-analytic review]. Revista Iberoamericana de Psicología y Salud, 9(1). https://doi.org/10.23923/i. rips.2018.01.011

Foshee, V. A., Reyes, H. L. M., Chen, M. S., Ennett, S. T., Basile, K. C., DeGue, S., \& Bowling, J. M. (2016). Shared risk factors for the perpetration of physical dating violence, bullying, and sexual harassment among adolescents exposed to domestic violence. Journal of Youth and Adolescence, 45(4), 672-686.

Gallego, R., Novo, M., Fariña, F., \& Arce, R. (2019). Child-to-parent violence and parentto-child-violence: A meta-analytic review. European Journal of Psychology Applied to Legal Context, 11(2), 51-59. https://doi. org/10.5093/ejpalc2019a4

Garrido, V., \& Casas, M. (2009). La prevención de la violencia en la relación amorosa entre adolescentes a través del taller "La Máscara del Amor". Revista de Educación, 349, 335 360.

Glick, P., \& Fiske, S. T. (1996). The Ambivalent Sexism Inventory: Differentiating hostile and benevolent sexism. Journal of Personality and Social Psychology, 70(3), 491-512. https:// doi.org/10.1037/0022-3514.70.3.491

Glick, P., \& Fiske, S. T. (2001). Ambivalent sexism. Advances in Experimental Social Psychology, 33, 115-188. https://doi.org/10.1016/ $\underline{\text { S0065-2601(01)80005-8 }}$

González-Ortega, I., Echeburúa, E., \& Corral, P. D. (2008). Variables significativas en las relaciones violentas en parejas jóvenes: Una revisión. Psicología Conductual, 16(2), 207225.

Hamby, S., \& Jackson, A. (2010). Size does matter: The effects of gender on perceptions of dating violence. Sex Roles, 63(5-6), 324331. https://doi.org/10.1007/s $11199-010$ 9816-0

Hyde, J. S. (2005). The gender similarities hypothesis. The American Psychologist, 60, 581-592.
Instituto Nacional de Estadística. (2018). Estadística de violencia doméstica y violencia de género. Año 2018 [Statistics of domestica and gender violence. 2018 year]. Retrieved from https://www.ine.es/prensa/ evdvg_2018.pdf

Izquierdo, S. A., \& Gómez-Acosta, A. (2013). Dependencia afectiva: Abordaje desde una perspectiva contextual [Affective dependence: An approach of contextual perspective]. Psychología. Avances de la Disciplina, 7(1), 81-91. Retrieved from http://www.scielo.org. co/pdf/psych/v7n1/v7n la08.pdf

Marcos, V., Gancedo, Y., Selaya, A., \& Novo, M. (2019). Analyzing the path from bullying to bully. In M. Novo \& D. Seijo (Eds), Psychology and Law: Research for practice (pp. 75-88). Santiago de Compostela: Walter de Gruyter. https://doi.org/10.2478/9788395669682007

Marroquí, M., \& Cervera, P. (2014). Interiorización de los falsos mitos del amor romántico en jóvenes [Internalitation of fake myths related to the romantic love among young people]. Reidocrea, 3(20), 142-146. Retrieved from https://digibug. ugr.es/bitstream/handle/10481/32269/

ReiDoCrea-Vol.3-Art.20-Marroqui-Cervera. pdf? sequence $=1$ \&isAllowed $=y$

Martínez-León, N. C., Mathes, E., Avendaño, B. L., Peña, J. J., \& Sierra, J. C. (2018). Psychometric study of the Interpersonal Jealousy Scale in Colombian samples. Revista Latinoamericana de Psicología, 50(1), 21 -30. http://dx.doi.org/10.14349/rlp.2018.v50. n 1.3

McHugh, M., \& Frieze, I. H. (1997). The measurement of gender-role attitudes: A review and commentary. Psychology of Women Quarterly, 21(1), 1-16. https://doi. org/10.1111/i.1471-6402.1997.tb00097.x Montolío, C. A., Ros, C. R., \& Portela, C. V. (2016). Programa para el contexto escolar de prevención de violencia en parejas adolescentes [Programa per al context escolar de prevenció de violència en la parella adolescent]. Educar, 52(1), 11-31. http://dx.doi.org/10.5565/rev/educar.673 
Moral, M. V., García, A., Cuetos, G., \& Sirvent, C. (2017). Violencia en el noviazgo, dependencia emocional y autoestima en adolescentes y jóvenes españoles [Dating violence, emotional dependence and self-esteem in spanish adolescents and young adult]. Revista Iberoamericana de Psicología y Salud, 8(2), 96-107. https://doi.org/10.23923/i. rips.2017.08.009

Morrish, L., Rickard, N., Chin, T. C., \& VellaBrodrick, D. A. (2018). Emotion regulation in adolescent well-being and positive education. Journal of Happiness Studies, 19(5), 15431564. https://doi.org/10.1007/s10902017-9881-y

Muñoz-Rivas, M. J., Redondo-Rodríguez, N., \& Ronzón-Tirado, R. C. (2019). Prevención de la violencia en parejas jóvenes: Evaluando el programa PREVIO [Dating violence prevention: Evaluation of the program PREVIO]. Revista de Psicología Clínica con Niños y Adolescentes, 6(3), 1-6. https://doi.org/10.21134/ rpcna.2019.06.2.1

Nava-Reyes, M. A., Rojas-Solís, J. L., Greathouse, L. M., \& Morales, L. A. (2018). Gender roles, sexism and myths of romantic love in Mexican adolescents. Revista Interamericana de Psicología, 52(1), 102-111. https://doi. org/10.30849/rip/ijp.v52i1.341

Novo, M., Fariña, F., Seijo, D., \& Arce, R. (2012). Assessment of a community rehabilitation in convicted male intimate-partner violence offenders. International Journal of Clinical and Health Psychology, 12(2), 219-234. Retrieved from http://www.aepc.es/iichp/articulos pdf/ ijchp-408.pdf

Novo, M., Fariña, F., Seijo, D., Vázquez, M. J., \& Arce, R. (2019). Assessing the effects of a parental separation education program on mental health problems. Psicothema, $37(3), \quad 284-291$. https://doi.org/10.7334/ psicothema2018.299

Novo, M., Herbón, J., \& Amado, B. G. (2016). Género y victimización: efectos en la evaluación de la violencia psicológica sutil y manifiesta, apego adulto y tácticas de resolución de conflictos [Victimization and gender: Effects in the evaluation of subtle and overt violence, adult attachment and conflict resolution tactics]. Revista Iberoamericana de Psicología y Salud, 7(2), 89-97. https://doi. org/10.1016/i.rips.2016.05.002

Özdemir, A., Utkualp, N., \& Palloş, A. (2016). Physical and psychosocial effects of the changes in adolescence period. International Journal of Caring Sciences, 9(2), 717.

Pradas, E. \& Perles, Novas, F. (2012). Relación del sexismo y dependencia emocional en las estrategias de resolución de conflictos de los adolescentes [Conflict resolution in adolescent couples, sexism and emotional dependence]. Quaderns de Psicología, 14(1), 45-60. https:// doi.org/10.5565/rev/apsicologia. 1041

Recio, P., Cuadrado, I., \& Ramos, E. (2007). Propiedades psicométricas de la Escala de Detección de Sexismo en Adolescentes (DSA) [Psychometric properties of the Adolescent Sexism Detection (ASD) Scale]. Psicothema, 19(3), 522-528. Retrieved from www. psicothema.com/pdf/3394.pdf

Rey-Anacona, C. A. (2013). Prevalencia y tipos de maltrato en el noviazgo en adolescentes $y$ adultos jóvenes [Prevalence and types of dating violence in adolescents and young adults] Terapia Psicológica, 37 (2), 143-154.

Rey-Anacona, C. A., Cruz, Y. C. G., Jiménez, V. S., \& Guajardo, E. S. (2017). Sexismo y agresiones en el noviazgo en adolescentes españoles, chilenos y colombianos. Behavioral Psychology/Psicología Conductual, 25(2), 297-315.

Reyes, H. L. M., Foshee, V. A., Niolon, P. H., Reidy, D. E., \& Hall, J. E. (2016). Gender role attitudes and male adolescent dating violence perpetration: Normative beliefs as moderators. Journal of Youth and Adolescence, 45(2), 350360. https://doi.org/10.1007/s10964-0150278-0

Rodríguez-Castro, Y., Lameiras-Fernández, M., Carrera-Fernández, M. V., \& Vallejo-Medina, P. (2013). La fiabilidad y validez de la escala de mitos hacia el amor: las creencias de los y las adolescentes [The reliability and validity of the Myths Scale toward Love: Adolescents' beliefs]. Revista de Psicología Social, 28(2), 157-168. 
Rodríguez-Díaz, F. J., Herrero, J., RodríguezFranco, L., Bringas-Molleda, C., PaínoQuesada, S. G., \& Pérez, B. (2017). Validation of dating violence questionnarie- $R$ (DVQ-R). International Journal of Clinical and Health Psychology, 17(1), 77-84. https://doi. org/10.1174/021347413806196708

Rothman, E. F., \& Xuan, Z. (2013). Trends in physical dating violence victimization among U.S. high school students, 1999-2011. Journal of School Violence, 13(3), 277-290. https://doi.org/10.1080/15388220.2013. 847377

Rubio-Garay, F., Carrasco Ortiz, M. A., \& GarcíaRodríguez, B. (2019). Moral disengagement and violence in adolescent and young dating relationships: An exploratory study. Revista Argentina de Clínica Psicológica, 28(1), 2231.

Rubio-Garay, F., Carrasco, M. Á., Amor, P. J., \& López-González, M. A. (2015). Factores asociados a la violencia en el noviazgo entre adolescentes: Una revisión crítica [Adolescent dating violence related factors: A critical review]. Anuario de Psicología Jurídica, 25(1), 47-56. https://doi.org/10.1016/i. api.2015.01.001

Rubio-Garay, F., López-González, M. Á., Carrasco, M. Á., \& Amor, P. J. (2017). Prevalencia de la violencia en el noviazgo: Una revisión sistemática [The prevalence of dating violence: A systematic review]. Papeles del Psicólogo, 38(2), 135-147.017. https:// doi.org/10.23923/pap.psicol2017.2831

Salovey, P., Mayer, J. D., Goldman, S. L., Turvey, C., \& Palfai, T. P. (1995). Emotional attention, clarity, and repair: Exploring emotional intelligence using the Trait Meta-Mood Scale. En J. W. Pennebaker (Ed.), Emotion, Disclosure, \& Health (p. 125-154).

Sánchez, N., Sobral, J., \& Seijo, D. (2017). El error judicial en el uso de la prisión preventiva: Personas en prisión que nunca llegan a ser condenadas [Judicial error in preventive prison: People in prison who will never be convicted]. Revista Iberoamericana de Psicología y Salud, 8(1), 1-8. https://doi. $\mathrm{org} / 10.23923 /$ i.rips.2017.08.004
Skvortsova, S. N., \& Shumskiy, V. B. (2014). Existential-phenomenological analysis of dependence in close interpersonal relationships. Existenzanalyse, 31 (1), 4-13.

Soller, B., Copp, J. E., Haynie, D. L., \& Kuhlemeier, A. (2020). Adolescent Dating Violence Victimization and Relationship Dissolution. Youth \& Society, 52(2), 187-208. https://doi. org/10.1177/0044118X17736537

Stappenbeck, C. A., Davis, K. C., Cherf, N., Gulati, N. K., \& Kajumulo, K. F. (2016). Emotion regulation difficulties moderate the association between heavy episodic drinking and dating violence perpetration among college men. Journal of Aggression, Maltreatment \& Trauma, 25(9), 921-935. https://doi.org/10.1080/10926771.2016. 1232328

Sunday, S., Kline, M., Labruna, V., Pelcovitz, D., Salzinger, S., \& Kaplan, S. (2011). The role of adolescent physical abuse in adult intimate partner violence. Journal of Interpersonal Violence, 26(18), 3773-3789.

Tuval-Mashiach, R., Walsh, S., Harel, S., \& Shulman, S. (2008). Romantic fantasies, crossgender friendships, and romantic experiences in adolescence. Journal of Adolescent Research, 23(4), 471-487. https://doi. org/10.1177/0743558407311332

Urbiola, I., \& Estevez, A. (2015). Dependencia emocional y esquemas desadaptativos tempranos en el noviazgo de adolescentes y jóvenes [Emotional dependency and early maladaptive schemas in adolescents and youth dating relationships]. Behavioral Psychology/Psicología Conductual, 23(3), 571-587.

Urbiola, I., Estévez, A., \& Iraurgi, I. (2014). Dependencia emocional en el noviazgo de jóvenes y adolescentes (DEN): Desarrollo y validación de un instrumento [Emotional dependency on courtship among youth (EDC): Development and validation of an instrument]. Ansiedad y Estrés, 20(2-3), 101 1145.

Vagi, K. J., O'Malley, E., Basile, K. C., \& VivoloKantor, A. M. (2015). Teen dating violence (physical and sexual) among US high school 
students: Findings from the 2013 National Youth Risk Behavior Survey. JAMA Pediatrics, 169(5), 474-482. https://doi.org/10.1001/ jamapediatrics.2014.3577

Viejo, C., \& Ortega-Ruiz, R. (2015). Cambios y riesgos asociados a la adolescencia. Psychology, Society \& Education, 7(2), 109118.

Viejo, C., Monks, C. P., Sánchez, V., \&Ortega-Ruiz, R. (2016). Physical dating violence in Spain and the United Kingdom and the importance of relationship quality. Journal of Interpersonal Violence, 31(8), 1453-1475. https://doi. org/10.1177/0886260514567963

Wincentak, K., Connolly, J., \& Card, N. (2017). Teen dating violence: a meta-analytic review of prevalence rates. Psychology of Violence, 7(2), 224-241. https://doi.org/10.1037/ a0040194
World Health Organization. (2014). Global status report on violence prevention 2014: executive summary. World Health Organization. Retrieved from https://apps.who.int/iris/bitstream/ handle/10665/145087/WHO NMH $\mathrm{NVI} 14.2$ eng.pdf? sequence $=3$ \&isAllowed $=y$ Yanez-Peñúñuri, L. Y., Martínez-Gómez, J. A., \& Rey-Anacona, C. A. (2019). Therapeutic intervention for victims and perpetrators of dating violence: A systematic review. Revista Iberoamericana de Psicología y Salud, 10(2), 107-121. https://doi.org/10.23923/i. rips.2019.02.029

Yela, C. (2003). La otra cara del amor: Mitos, paradojas y problemas. Encuentros en Psicología Social, 1 (2), 263-267. 